\title{
Land Use Policy of Agroforestry: Case Study of Protected Area Changes in Sekaroh Forest, East Lombok West Nusa Tenggara
}

\author{
Aminah, Nur Adhim, I Gusti Ayu Gangga Santi Dewi* \\ Faculty of Law, Diponegoro University, Semarang, Indonesia
}

Received July 28, 2021; Revised August 31, 2021; Accepted October 6, 2021

\section{Cite This Paper in the following Citation Styles}

(a): [1] Aminah, Nur Adhim, I Gusti Ayu Gangga Santi Dewi, "Land Use Policy of Agroforestry: Case Study of Protected Area Changes in Sekaroh Forest, East Lombok West Nusa Tenggara," Environment and Ecology Research, Vol. 9, No. 5, pp. 261 - 270, 2021. DOI: 10.13189/eer.2021.090506.

(b): Aminah, Nur Adhim, I Gusti Ayu Gangga Santi Dewi (2021). Land Use Policy of Agroforestry: Case Study of Protected Area Changes in Sekaroh Forest, East Lombok West Nusa Tenggara. Environment and Ecology Research, 9(5), 261 - 270. DOI: 10.13189/eer.2021.090506.

Copyright $\bigcirc 2021$ by authors, all rights reserved. Authors agree that this article remains permanently open access under the terms of the Creative Commons Attribution License 4.0 International License

\begin{abstract}
The condition of existing forest use in Sekaroh, East Lombok is dominated by forest change function to increase the production of corn, leading to the massive deforestation. The research is to analyze the deforestation and land use conversion in Sekaroh, East Lombok. It is also to analyze local government policies in facing the rampant conversion of forest function to corn plantations in East Lombok. The research was conducted using the socio legal method with a qualitative approach with evidence-based data analysis to demonstrate the deforestation and economic interest of corn production in local level. The results showed that forest protection is part of forest management which falls under the authority of the central government and local governments. The implementation of forest protection aims to protect the forest area and its environment so that the protection function, conservation function and production function can be achieved optimally and sustainably. Moreover, the policy also needs to consider the limited production forest and geographic conditions in local context considering that the function of production forest is limited to maize plantations.
\end{abstract}

Keywords Land Use Policy, Natural Resources Management, Deforestation, Agroforestry, Law Enforcement

\section{Introduction}

Forests as part of national natural resources have an important role in various aspects of economic, social and environmental life [1 -3]. In an international agreement, it is stated that forests, which have an important function for the life of the world, must be developed and protected from various damages to the world's ecosystems. Development on renewable natural resources must be managed in such a way that the main function of the forest can always be maintained [4]. Non-renewable natural resources should be used as economically as possible with the most optimal results. Forestry development to increase forest utilization for Indonesian domestic industries must generate added value and create jobs. On the island of Lombok, West Nusa Tenggara (NTB), many protected forest areas have turned into corn plantations. The production forest area is part of the cultivation area, namely limited production forest and permanent production forest. In protected forest, there is a high forest function change with a percentage above $50 \%$, based on latest data from NTB Agriculture and Plantation Office (Table 1).

Table 1 showed that protected forest areas with an area of 15,881.65 hectares are scattered in East Lombok-NTB Regency. From data from the NTB Agriculture and Plantation Office, in 2014, the corn area was 126,577 hectares. It significantly increased to 310,990 hectares and production of $2,127,324$ tons in 2017. In 2018, the 
production was 2,959,222 tons. In the case of protected forest area located in Sekaroh, Jejowaru district, the forest area has also have turned into plantation area. Generally, the conversion of function is dominated by the conversion of protected forest areas to maize plantations (36.29\%) and rainfed rice fields $(10.40 \%)$.

Table 1. Land Use of Corn Plantation and Production, NTB, 2014-2017

\begin{tabular}{|c|c|c|c|c|}
\hline Data & Allotment & Size & Unit & $\begin{array}{c}\text { y-o-y } \\
\text { growth }\end{array}$ \\
\hline 2014 & $\begin{array}{c}\text { Plantation } \\
\text { area }\end{array}$ & 126,577 & hectares & - \\
\hline 2015 & $\begin{array}{c}\text { Production } \\
\text { area }\end{array}$ & 785,864 & tons & - \\
\hline 2016 & $\begin{array}{c}\text { Plantation } \\
\text { area }\end{array}$ & 206,997 & hectares & $44.63 \%$ \\
\hline 2017 & $\begin{array}{c}\text { Production } \\
\text { area }\end{array}$ & $1,101,244$ & tons & $14.72 \%$ \\
\hline & Production & $2,127,324$ & tons & $93.17 \%$ \\
\hline
\end{tabular}

Source: [5]

Basically, one of the functions of a protected forest is to become a water catchment area and maintain water supplies in an area [6]. The forest function conversion in East Lombok Regency, especially in the research area in Sekaroh, has resulted in a lack of water supply [7]. Therefore, it is necessary to provide treatment in this protected forest area. On the other side, corn (Zea mays) is one of the main food crops in Indonesia and is one of the most cultivated food crops by farmers in East Lombok. Apart from food and animal feed, corn is also widely used in the food, beverage, chemical and pharmaceutical industries. The Sekaroh community independently cleared unproductive forests and planted corn. Increased corn plantations penetrated forest areas. Social forestry has replaced maize plantations and large trees have been eliminated. The social forestry program works, but the annuals between trees do not last long. Small trees and shrubs were burned then replaced by corn. This has resulted in deforestation of almost all forests in Jejowaru District, especially Sekaroh. Geist \& Lambin [8] divided the causes of deforestation into 3 groups, namely direct causes, basic causes, and biophysical causes. Direct causes are human activities that directly affect the condition of forest cover and its functions such as timber exploitation, expansion of agricultural areas, plantations, settlements, industries, and so on [9]. The basic causes are usually complex factors such as social, political, economic, cultural and demographic factors. Meanwhile, most of the biophysical causes come from natural factors [10]. The protected forest in Sekaroh, covering an area of 2,834.20 hectares, is bordered by Pink Beach and Tanjung Ringgit for tourism. The conflict between the Ministry of Environment and Forestry and farmers lasted a long time in this forest area. The residents are adamant that they also have the right to manage the forest area. The government has repeatedly put things in order because there has been a lot of deforestation. The research will discuss about the reality of forest function conversion in Sekaroh, East Lombok and whether local government policies face the rampant conversion of forest function to corn plantations in East Lombok.

\section{Literature Review}

In jurisprudence, the term 'policy' is the basis or line of attitudes or guidelines for implementation and decision making [11]. Based on State Administrative Law, policy in the sense of policy should not be confused with policy as the foundation of Freies Ermessen [12]. Talking about policy or law as a system that works in society, Friedman [13] argues that there are components contained in law, namely structural components are parts that move in a mechanism, for example in implementing policies related to reclamation. Substantial components are the actual results published by the legal system and include unwritten legal rules. Meanwhile, the culture component is the values and attitudes that bind the legal system together and produce a form of law enforcement in the culture of society as a whole $[14,15]$. These three components determine each other, as well as influence one another. Analysis through the systems approach examines that although the component of the legal substance has good output, it will not run well if it is not supported by other components or subsystems, in this case the structural and cultural components or legal culture. Therefore, in making a policy, it must be in line with legal objectives that can provide certainty, benefit and justice for the community, including in forestry sector that needs the community awareness on its conservation and sustainability [16].

Regarding the transfer policy of function of protected forest, protected forest is a forest area which has the main function of protecting life support systems to regulate water systems, prevent flooding, control erosion, prevent seawater intrusion, and maintain soil fertility. Change of forest area function or forest function change is a change in part or all of the functions of a forest in one or several forest groups to become the function of another forest area [17, 18]. The function of the forest area is determined to be some characteristics. First, conservation forest consists of nature reserve forest area (nature reserves and wildlife reserves), nature conservation forest area (national park, forest park and natural tourism parks). The second is protected forest, and the third is production forest which consists of permanent production forest and convertible production forest $[19,20]$.

Conversion of land functions or commonly referred to as land conversion is a change in the function of part or all of the land area from its original function, as planned into 
other functions that have a negative impact on the environment and the potential of the land itself [21 - 23]. The condition of forest conversion in several areas is currently increasing and worrying for the ecological conditions and the surrounding ecosystem, especially mountainous areas where protected forest land has become agricultural land, plantation land or converted into community housing which is legalized by the local government, central government or form of occupation due to the factor of the increasing population level [24-26].

According to Sumaryoto [27], land conversion actors can be divided into two. First, direct transfer of function by the owner of the land concerned. Typically, there are 3 motives for action, that are, to meet the need for housing, to increase income through business transfer and the combination of both, for example, to build a house that is also used as a place of business. The process of land conversion can basically be seen as a form of logical consequence of the growth and transformation of changes in the socio-economic structure of a developing community [28]. This development is reflected in the growth of natural resource utilization activities due to the increasing demand for land use as a result of an increase in population and per capita needs. Also, there is a shift in the contribution of development sectors from primary sectors, especially from agriculture and natural resource processing to secondary such as manufacturing and tertiary sectors such as services [29].

Article 19 paragraph (1) of Law No. 41 of 1999 concerning Forestry explicitly states that to make changes to the designation and function of forest areas must be based on integrated research which is operationally regulated through the Decree of the Minister of Forestry No. 70/Kpts-II/2000. Meanwhile, the assessment is carried out by an integrated team in accordance with the Decree of the Minister of Forestry No. 1615/Kpts-VII/2001. With the issuance of Law No. 41 of 1999, activities to change the designation and function of forest areas are not easily implemented considering that in addition to these changes are based on the criteria as stated in Government Regulation No. 47 of 1997, Government Regulation No. 68 of 1998, Presidential Decree No. 32/1992, Ministerial Decrees, also need to be recommended by the provincial and district governments, and must be based on an integrated assessment by the integrated team. However, if it has an important impact and is broad in scope and has strategic value, legislative approval is required.

\section{Method}

The research is to analyze the policy to prevent the forest function transfer from forest to agricultural use in Sekaroh Village, East Lombok District, West Nusa Tenggara (NTB), Indonesia. The study was conducted by using the socio legal method with a qualitative approach. The data were collected to support the conclusion-based evidence in revealing the deforestation, forest function transfer, and corn-based agricultural production. The data were collected from NTB Agriculture and Plantation Office from 2014 to 2019. Moreover, the data were also obtained from Sekaroh Village Government regarding the population and administrative division (Table 2). The maps were also displayed to demonstrate the research object both to denote the land use in general and the Sekaroh forest in particular.

This approach used in this study remains in the realm of law to highlight the significant influence of policy measures to prevent the deforestation in local sphere, as well as to harmonize the economic interest to increase the production of corn as one of the most important commodities of NTB and the interest to preserve the natural environment.

Table 2. Population and Administrative Division in Sekaroh

\begin{tabular}{|c|c|c|c|c|c|}
\hline No & Hamlets & Household & Male & Female & Total \\
\hline 1 & Aro Inak & 164 & 283 & 280 & 563 \\
\hline 2 & Pengoros & 179 & 320 & 338 & 658 \\
\hline 3 & Sunut & 179 & 302 & 297 & 599 \\
\hline 4 & Telone & 137 & 245 & 239 & 484 \\
\hline 5 & Transmigrasi & 205 & 333 & 358 & 691 \\
\hline 6 & Ujung Gol & 143 & 213 & 245 & 458 \\
\hline \multirow[t]{2}{*}{7} & $\begin{array}{c}\text { Ujung } \\
\text { Ketangge }\end{array}$ & 223 & 388 & 389 & 777 \\
\hline & Total & 1230 & 2084 & 2146 & 4230 \\
\hline
\end{tabular}

Source: [30]

The data in this study were obtained through observation activities, interviews, interpretation of documents or text, and personal experience. In-depth interviews were conducted with open-ended questions, especially for informants who had a lot of information. The interviews were conducted with many stakeholders in the region, such as the Environment and Forestry Office (LHK) of NTB Province, and Sekaroh village government. The observation was also done to highlight the function of Indonesian public forestry company (Perum Perhutani), their employees as forestry police, and structural officials of central and regional forestry agencies to show their duties and functions, authority and responsibility in the field of forest protection. 
Land Use Policy of Agroforestry:

Case Study of Protected Area Changes in Sekaroh Forest, East Lombok West Nusa Tenggara

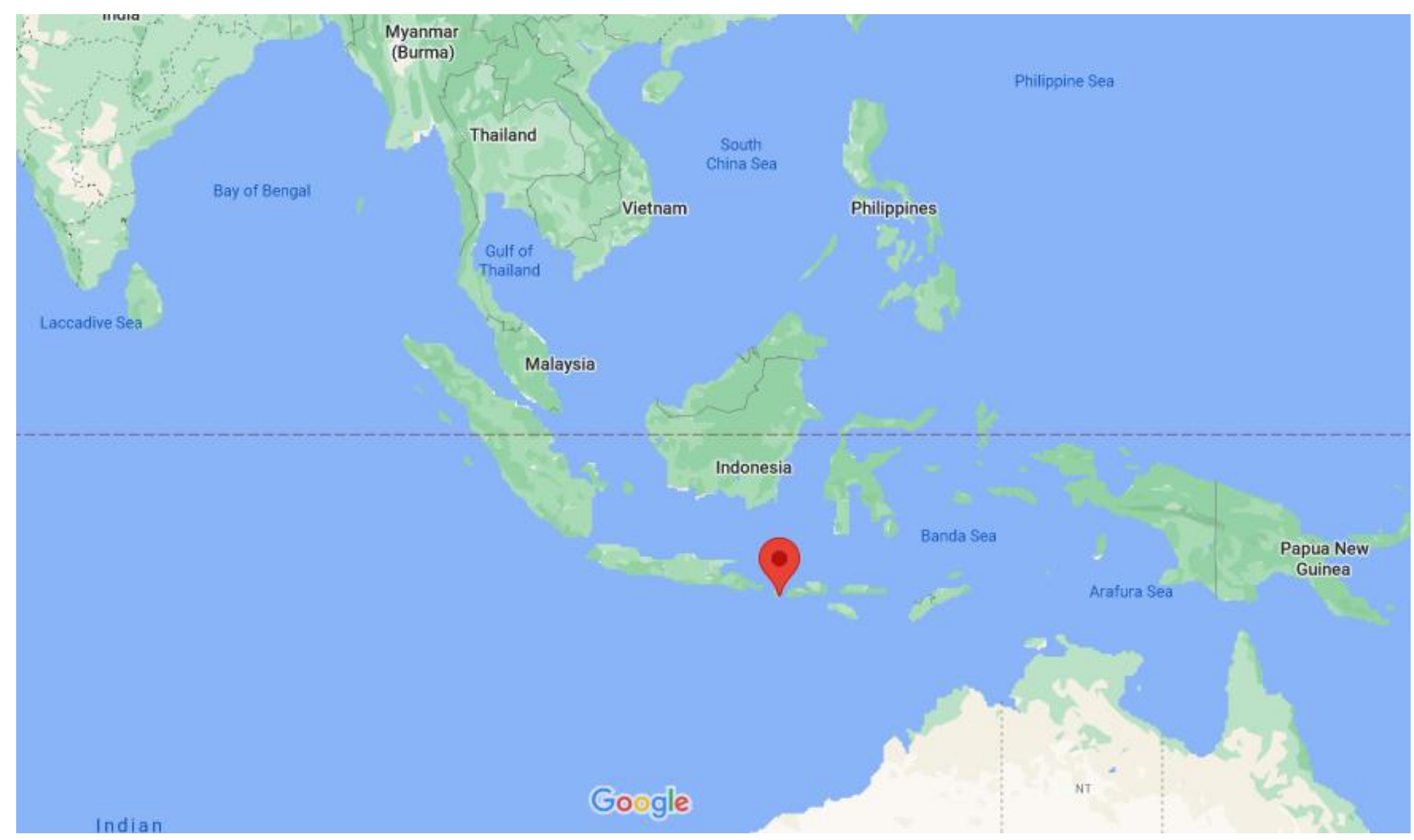




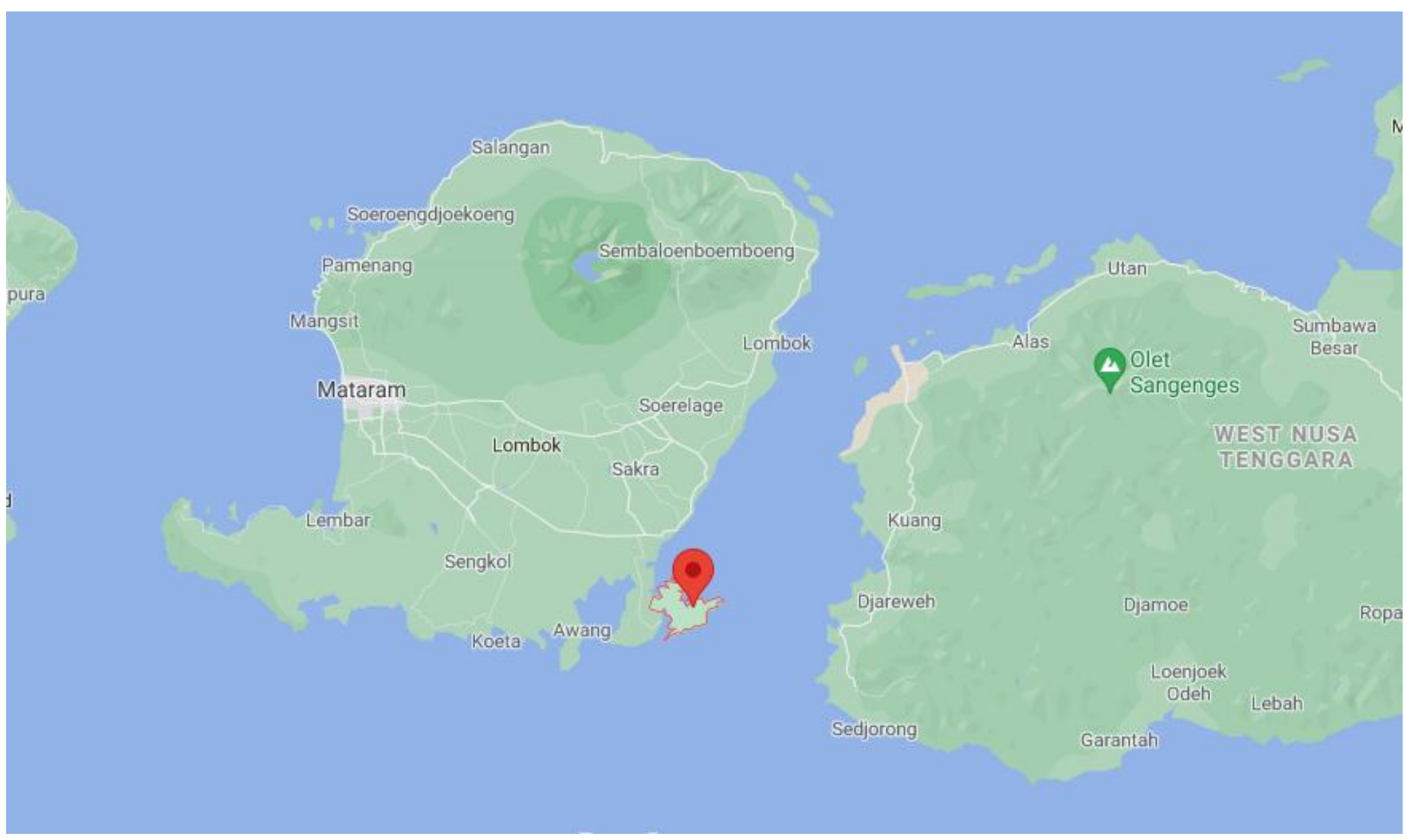

(b)

Figure 1. Location of Sekaroh

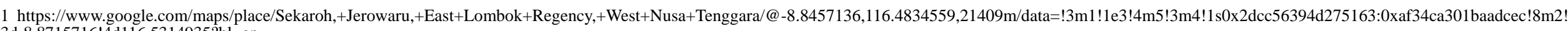
3d-8.8715716!4d116.5314935?hl=en. 


\section{Planted Area vs Corn Production}

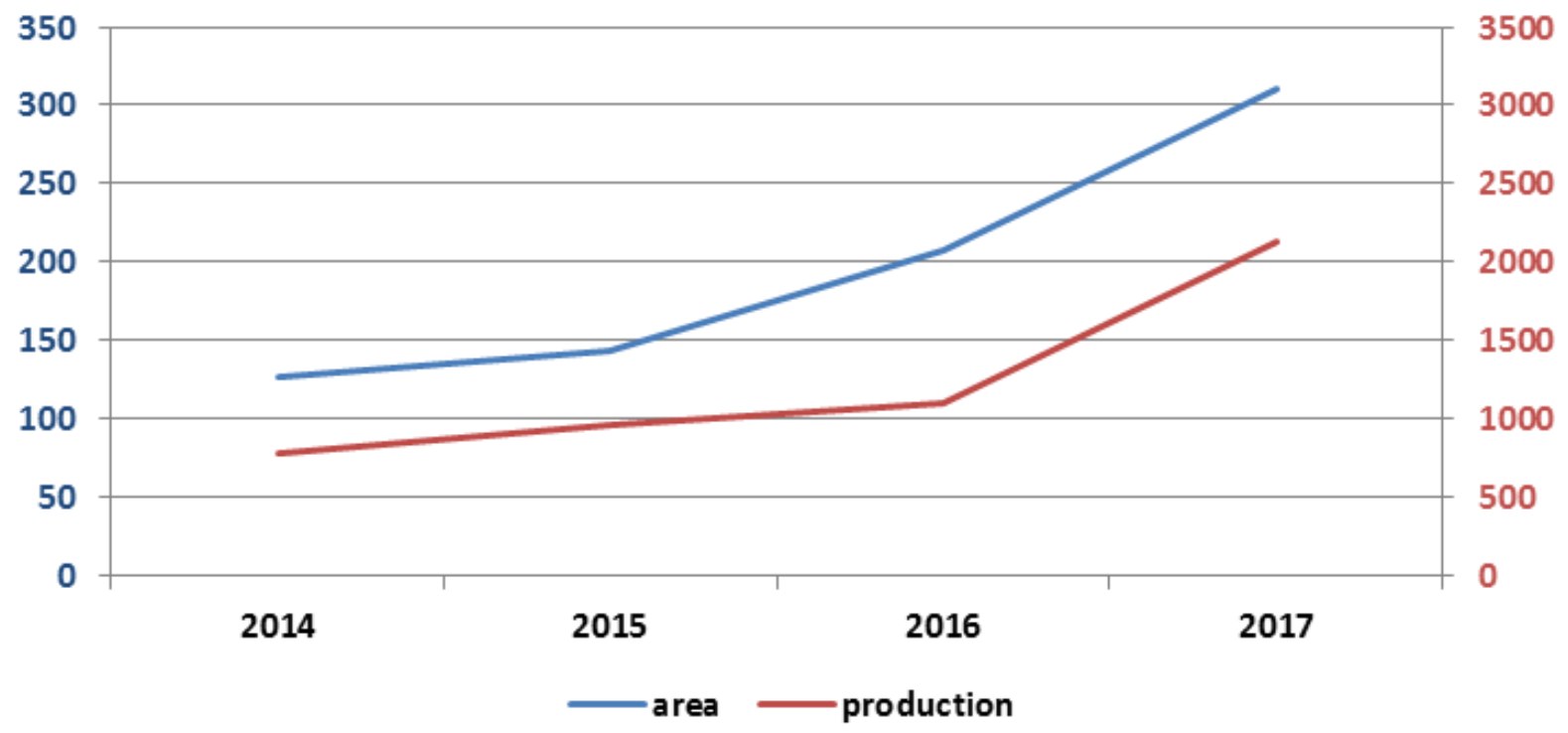

Source: data processed

Figure 2. Correlation of planted area and corn production, East Lombok, 2014-2017

\section{Results}

The results of interviews with the Environment and Forestry Office (LHK) of NTB Province, the motive of encroachment on Lombok Island is illegal logging with the clearing of new forests used for corn plantations. From the data obtained, the total encroached area reaches 131,990.87 hectares. The data are still outside the enclave, conservation area, body of water. The Secretary of the NTB Provincial LHK Service said that forest conversion occurs in forests with social forestry status in protected forests. In fact, 90,000 hectares of them are completely deforested. Of the 90,000 hectares of damaged social forestry areas, only 23,000 hectares have been cultivated by the community.

Along with the economic interest to increase corn production as the main commodity in NTB Province, encroachment is increasing year by year. This study found a positive correlation between planted area and production from 2014 to 2018. As a result, the need for land for planting corn is increasingly encroaching on protected forests. The analysis shows that from 2014 to 2017, the growth of maize production area reached $245.69 \%$ in the province of NTB from 126577 ha in 2014 to 310,990 ha in 2017. Specifically at the local level, this is also very influential on massive deforestation in the form of reduced forest area in Sekaroh.

To prevent deforestation, some measures were taken at the provincial level. The policy of the Governor of West Nusa Tenggara is to restore the forest area by tightening social forestry permits. Community groups that become partners can choose three schemes, namely Community
Forest $(\mathrm{HKm})$, partnership forest and Community Plantation Forest (HTR), according to conditions in the field. The monitoring mechanism is carried out by the Forest Protection Unit (KPH) Team of each region. The rules apply within the group and if someone cuts them down, they will be sanctioned by other members, for example, removed from membership. Hence, supervision has an important role to play in achieving predetermined goals. If this supervision is not carried out, it is likely that irregularities and errors will occur continuously so that it will be difficult to fix it. Therefore, to ensure and ensure that all implementation can take place and succeed in accordance with what is planned, supervision is needed so that the goals are achieved in accordance with what has been set [31]. Supervision is carried out based on existing Regional Regulations in order to support all activities or efforts undertaken so that acts of destroying forests and the environment can be prevented [32].

There are two kinds of efforts to defend the state's rights over forests, namely forest protection efforts or what is called forest technical safeguards; and forest protection efforts or what is called forest police security efforts. Forest supervision, apart from being given to related agencies and the surrounding community, is also given to authorized officials, namely the special police given authority. This authority is to conduct patrols in forest areas or their jurisdictions; examine documents or documents relating to the transportation of forest products within the forest area or its jurisdiction; receive reports of criminal acts involving forests, forest areas and forest products; seek information and evidence of the occurrence of a criminal act relating to forests, forest areas and forest products. In the event that 
someone is caught in the act, it is obligatory to arrest the suspect to be handed over to the authorities; and make reports and sign reports on the occurrence of criminal acts relating to forests, forest areas and forest products (Article 51 paragraph 2 of the Forestry Law). Forestry police authorities include preventive activities and actions, administrative measures and repressive operations (Gov. Reg. of Forest Protection Article 36 paragraph 1).

Certain forestry officials who have special police powers include civil servants who are appointed as functional officers of the forestry police; Indonesian public forestry company (Perum Perhutani) employees who are appointed as forestry police; structural officials of central and regional forestry agencies who are in accordance with their duties and functions have the authority and responsibility in the field of forest protection (Gov. Reg on Forest Protection Article 32 paragraph 2). The policy of the Environment and Forestry Service of West Nusa Tenggara Province to carry out the Regional Government's Authority as regulated in Government Regulation No. 23 of 2021 concerning Forestry Implementation, supervision is carried out by the following steps. The first is socialization. Socialization is a part of marketing in every activity. Meanwhile, socialization is the main activity carried out by entrepreneurs and the government in order to achieve goals. In this case, socialization activities have been carried out, but people have ignored the socialization that has been carried out. Therefore, law enforcement to protect the environment to balance the interest of agroforestry and agroecology is needed [33, 34].

The second is patrol. Patrol duties are routine activities carried out by the forestry police, so that the preventive function runs properly. To get optimal results, the patrols must be well planned, so that when they find forest disturbances while on patrol, the forestry officers already know what data and information should be collected. Therefore, guidance is needed in patrolling, so that patrol activities run in accordance with existing operational standards. Routine, functional, and forest fire control patrols, which are carried out in patrols are prevention and law enforcement. Based on the results of an interview with the Secretary of the Environment and Forestry Office of West Nusa Tenggara Province, that we are constrained by a lack of personnel and places that are difficult to reach we only conduct patrols once a year. In patrols, various actions are carried out, namely preventive measures, security measures and legal actions. In law enforcement at the Environment and Forestry Office of West Nusa Tenggara Province, this is carried out by the Civil Servant Investigator (PPNS), this is also held by the Forestry Police. In legal proceedings, they are given a warning letter first, the first and second warnings, but if they have already given the second warning, they still ignore the warnings given by being forced to take legal channels. Action is carried out very firmly in order to create a sustainable forest and free from people who can only damage the function of the protected forest [35].

The third is licensing. In Article 50 Paragraph 2 of Law No. 41 of 1999 it is explained that to open a plantation area or whatever it is in a protected forest area must first have a permit from the Government, but after the authors made initial observations there, they said that they did not have any permits, they only cleared land plantation because there is a very good location for corn plantations. Forest protection problems occur in the district of Central West Nusa Tenggara, one of which is in the protected forest area in Sekaroh. Some of the communities described above live in the protected forest area of Sekaroh, they manage the protected forest into plantation land. By managing the land, they get the results that are intended for economic needs. For them it has greatly helped their economy with satisfactory results. In this case they use the protected forest area known as the Sekaroh Protected Forest to become plantation land, one of which is corn plantations. The area that they use as a corn plantation is a protected forest area that should not be used for personal gain and the community works on the forest land without using a permit from any party. 
Initially, there were only a few of these corn plantation businesses, but because many of the people here did not work, over time this business developed and other communities also started and owned their own plantation land by clearing land in the protected forest area of Sekaroh because it could produce income. The lack of ability, competence and professionalism possessed by human resources is an inhibiting factor in supervising local governments in protecting forests in the protected forest area of Sekaroh. The imposition of legal or administrative sanctions on corn plantation owners who do forest encroachment that is not in accordance with the stipulated regulations does not work. And no sanctions are given to entrepreneurs and forest communities who commit forest encroachment. The lack of strict sanctions against forest encroachers is also an inhibiting factor in the supervision of local governments in protecting forests in the Protected Forest area in Sekaroh. Lack of facilities and infrastructure owned by the Environment and Forestry Office of West Nusa Tenggara Province, especially funds or budgets to support the implementation of protected forest conservation, because adequate facilities and infrastructure will certainly hinder the implementation of an activity such as the budget that is owned, especially the area of protected forest that is managed in Sekaroh is vast. Facilities and infrastructure in carrying out supervision in protecting forests in the protected forest area in Sekaroh are very important because of the difficulty of the location coverage to carry out such supervision.

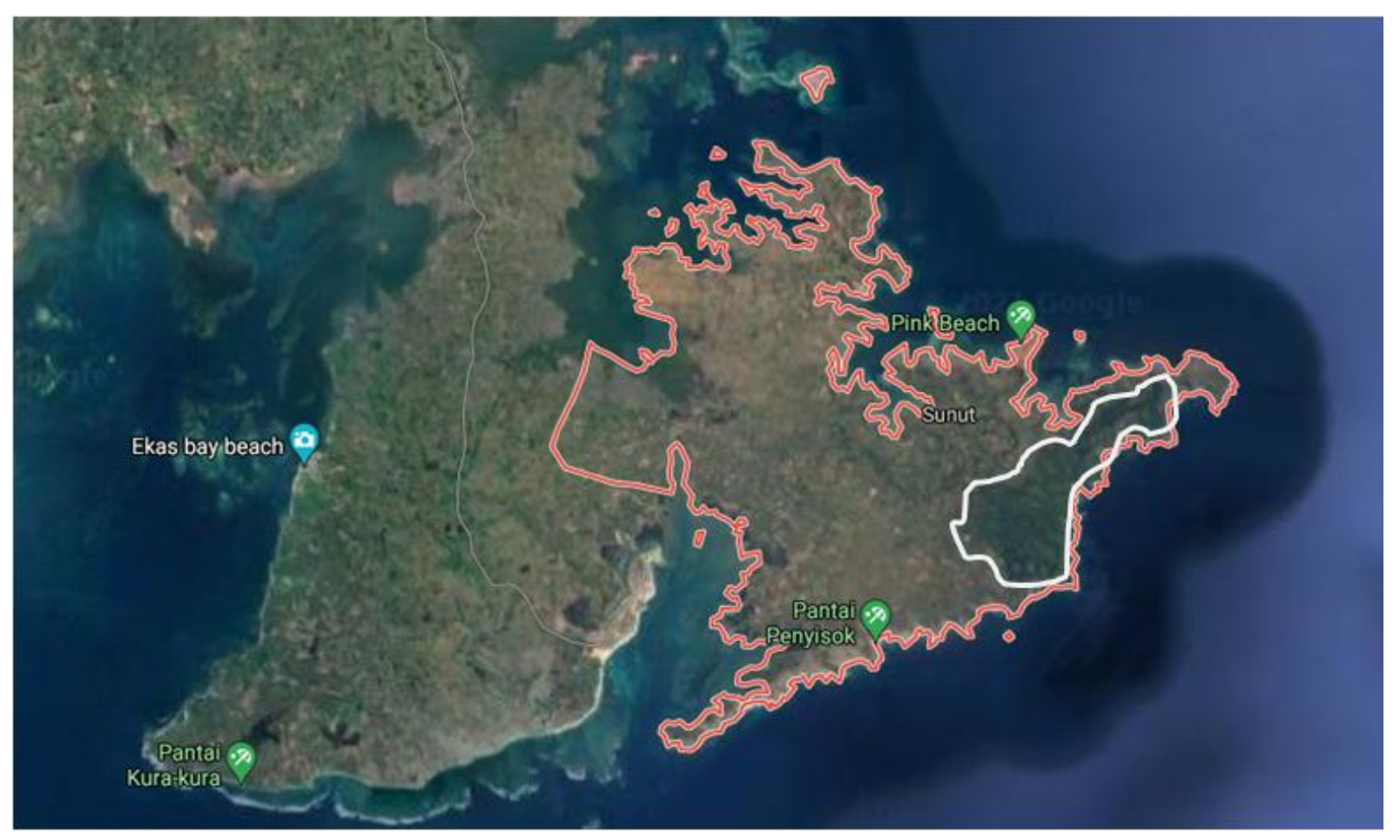

Source: Google Maps $2021^{2}$

Figure 3. Sekaroh village and Sekaroh forest 


\section{Conclusions}

The results revealed that forest protection is part of forest management which falls under the authority of the central government and local governments. The implementation of forest protection aims to protect the forest area and its environment so that the protection function, conservation function and production function can be achieved optimally and sustainably. Forest protection is an effort to prevent and limit damage to forests, forest areas and forest products caused by human actions, livestock, fires, natural forces, pests and diseases.

The results of the study also show the low awareness of the local community in protecting the protected forest. This is one of the important factors in deforestation and land conversion in Sekaroh and NTB in general. As a result, ecological function disturbances and imbalances in natural ecosystems occur, which can adversely affect the quality of the environment and the frequency of natural disasters, such as floods and landslides. This is a very fatal thing and damages the forest where the function of the forest is to protect the ecosystem contained therein. To overcome this, it is not only from the Government that continues to provide socialization and tight supervision. However, the community itself must have full awareness of the consequences of encroachment of the protected forest by opening new land into production land which is carried out in an ecologically sustainable manner and is natural forest resources.

Moreover, in order to prevent and maintain and protect forests, forest areas and forest products from damage caused by human actions, the provincial government through Environment and Forestry Office and local governments as well as community leaders conduct socialization and extension of laws and regulations in the forestry sector; carry out an inventory of problems; encourage increased productivity of society; facilitate the formation of community institutions; increasing community participation in forest management activities; cooperate with rights or permit holders; increase the effectiveness of coordination of forest protection activities; encouraging the creation of alternative livelihoods for the community; increase the effectiveness of reporting the occurrence of security disturbances; take the first necessary action against forest security disturbances; and or impose sanctions for violation of the law.

\section{REFERENCES}

[1] C. Cambero, T. Sowlati, "Assessment and optimization of forest biomass supply chains from economic, social and environmental perspectives-A review of literature," Renewable and Sustainable Energy Reviews, vol. 36, pp. 62-73, 2014.
[2] C. J. P. Colfer, "The politics of decentralization: forests, power and people," London: Earthscan, 2012.

[3] Q. Grafton, W. Adamowicz, D. Dupont, H. Nelson, R. J. Hill, S. Renzetti, "The economics of the environment and natural resources,” John Wiley \& Sons, 2008.

[4] P. Ekins, "Identifying critical natural capital: Conclusions about critical natural capital," Ecological economics, vol. 44, no. 2-3, pp. 277-292, 2003.

[5] NTB Agriculture and Plantation Office, "Capaian Kinerja Distanbun Prov NTB Tahun 2019," NTB Agriculture and Plantation Office, 2019. Retrieved from: https://distanbun.ntbprov.go.id/download_dokumen2.php?id $=14$.

[6] R. Kurniawan, "Conservation of Indonesian Tropical Forests as the Lungs of the World," Inkalindo Environmental Journal, vol. 1, no. 1, pp. 62-66, 2020.

[7] J. S. Adiansyah, "Correlation Analysis between River Water Quality and Community Socio-Economic Condition: Case Study of Jangkok River, Mataram City," Inkalindo Environmental Journal, vol. 1, no. 1, pp. 49-61, 2020.

[8] H. J. Geist, E. F. Lambin, "What drives tropical deforestation," LUCC Report series, vol. 4, pp. 116, 2001.

[9] F. Achard, H. D. Eva, H. J. Stibig, P. Mayaux, J. Gallego, T. Richards, J. P. Malingreau, "Determination of deforestation rates of the world's humid tropical forests," Science, vol. 297, no. 5583, pp. 999-1002, 2002.

[10] A. Loza, “A Spatial Logistic Regression Model for Tropical Forest Conversion, A case study of the Carrasco province (1986-2002)," Bolivia: Doctoral dissertation, Msc thesis, ITC, Enschede, 2004.

[11]E. Syarief., "Electronic Land Certificates: Its Goals and Challenges," Research Horizon, vol. 1, no. 4, pp. 120-125, 2021.

[12] Andriansyah, E. S. Sulastri, E. S. Satispi, "The Role of Government Policies in Environmental Management," Research Horizon, vol. 1, no. 3, pp. 86-93, 2021.

[13]L. M. Friedman, "The legal system: A social science perspective," Russell Sage Foundation, 1975.

[14]B. Z. Tamanaha, "A general jurisprudence of law and society," Oxford University Press on Demand, 2001.

[15] O. Sadma, "The Role of Environmental-Based "Green Startup" in Reducing Waste Problem and its Implication to Environmental Resilience," Research Horizon, vol, 1, no. 3, pp. 106-114, 2021.

[16] J. Tomićević, M. A. Shannon, M. Milovanović, "Socio-economic impacts on the attitudes towards conservation of natural resources: Case study from Serbia," Forest Policy and Economics, vol. 12, no. 3, pp. 157-162, 2010.

[17] B. E. Turisno, I. G. A. G. S. Dewi, "Impact of coastal reclamation on environmental sustainability and tourism-based economy on the north coast of java," International Journal of Criminology and Sociology, vol. 10, no. 1, pp. 695-702, 2021. 
[18] I. G. A. G. S. Dewi, "Legal review of positive impact of beach reclamation in pekalongan city," International Journal of Scientific and Technology Research, vol. 8, no. 11, pp. 1289-1292, 2019.

[19] B. E. Turisno, R. Suharto, E. A. Priyono, S. Mahmudah, S. M. Badriyah, "Analysis of the Role Model Of Coastal Area Arrangement On Improving Community Welfare Through Legal Perspective," Journal of Legal, Ethical and Regulatory Issues, vol. 24, no. 6, pp. 1-19, 2021.

[20] M. Ali, A. Tahir, F. Faisal, I. Irnawati, P. Pujiyono, B. N. Arief, "Criminological Outlook of Overcoming Disproportionate Punishment in Environmental Crimes," International Journal of Criminology and Sociology, vol. 10, pp. 22-32, 2021.

[21] W. M. Achten, A. Trabucco, W. Maes, L. V. Verchot, R. Aerts, E. Mathijs, ... B. Muys, "Global greenhouse gas implications of land conversion to biofuel crop cultivation in arid and semi-arid lands-Lessons learned from Jatropha," Journal of Arid Environments, vol. 98, pp. 135-145, 2013.

[22] S. Brown, A. E. Lugo, "Rehabilitation of tropical lands: a key to sustaining development," Restoration ecology, vol. 2, no. 2, pp. 97-111, 1994.

[23] N. Van Vliet, O. Mertz, A. Heinimann, T. Langanke, U. Pascual, B. Schmook, ... A. D. Ziegler, "Trends, drivers and impacts of changes in swidden cultivation in tropical forest-agriculture frontiers: a global assessment," Global Environmental Change, vol. 22, no 2, pp. 418-429, 2012.

[24] C. Nasirin, A. Lionardo, "Decentralization, Public Services and Neglected Children in Mataram City, West Nusa Tenggara," Research Horizon, vol. 1, no. 2, pp. 55-61, 2021.

[25] B. E. Robinson, M. B. Holland, L. Naughton-Treves, "Does secure land tenure save forests? A meta-analysis of the relationship between land tenure and tropical deforestation," Global Environmental Change, vol. 29, pp. 281-293, 2014.

[26]E. B. Barbier, J. C. Burgess, "The economics of tropical deforestation," Journal of Economic Surveys, vol. 15, no. 3, pp. 413-433, 2001.

[27] W. Ariyadi, "Empirical Analysis of Farmers Household Food
Security Levels in Salatiga, Indonesia," Research Horizon, vol. 1, no. 1, pp. 39-46, 2021.

[28] K. Magis, "Community resilience: An indicator of social sustainability," Society and Natural Resources, vol. 23, no. 5, pp. 401-416, 2010.

[29] N. Adhim, S. Sukirno, M.A. Mahfud, “Actualization of land social function in resolving land conflict in an urban area (Land case study of buildings in ujungberung, Bandung city)," International Journal of Innovation, Creativity and Change, vol. 9, no. 9, pp. 117-131, 2019.

[30] Sekaroh Village Government, "Data Demografi Berdasar Populasi Per Wilayah,” Sekaroh Village Government, 2021. Retrieved from Sekaroh Village Official Website, Jerowaru District, East Lombok Regency, West Nusa Tenggara Province, https://www.desasekaroh.web.id/first/wilayah.

[31] S. Sukirno, N. Adhim, "Sociological Perspective and Legal Protection of Customary Land: Solution to Determination of Traditional Forest in Indonesia," International Journal of Criminology and Sociology, vol. 10, no. 1, pp. 960-962, 2021.

[32] I. Permana, R. Dewi, J. Budhiana, I. Mariam, L. Novianty, R. N. Utami, W. Sanjaya, A. R. La Ede, "Socio-Cultural Approach on Disaster Risk Management of Sirnaresmi Customary Village, West Java," Research Horizon, vol. 1, no. 4, pp. 136-142, 2021.

[33] L. L. Lelamo, A. W. Kemal, "Distribution and Regeneration Status of Cordia africana (Lam.) Tree in Agroforestry Practices along Agroecology and Farmers' Wealth Status in Sidama Zone Southern Ethiopia," Universal Journal of Agricultural Research, vol. 9, no. 3, pp. 70 - 78, 2021. DOI: 10.13189/ujar.2021.090302.

[34] A. M. Noon, H. G. I. Ahmed, S. O. Sulaiman, "Assessment of Water Demand in Al-Anbar Province- Iraq," Environment and Ecology Research, vol. 9, no. 2, pp. 64 - 75, 2021. DOI: 10.13189/eer.2021.090203.

[35] A. Syaufi, A. F. Zahra, Mursidah, "The Existence of Customary Law: Badamai Customary Law," Research Horizon, vol. 1, no. 3, pp. 94-99, 2021. 